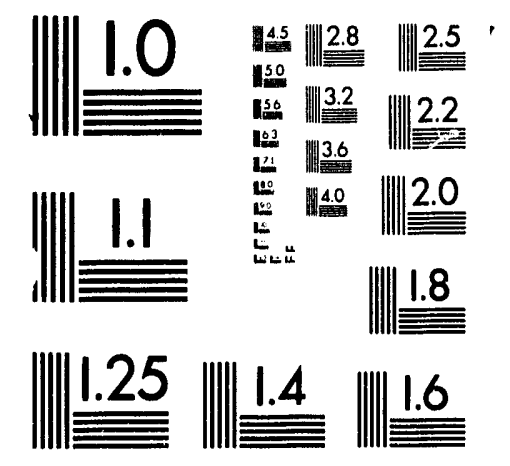



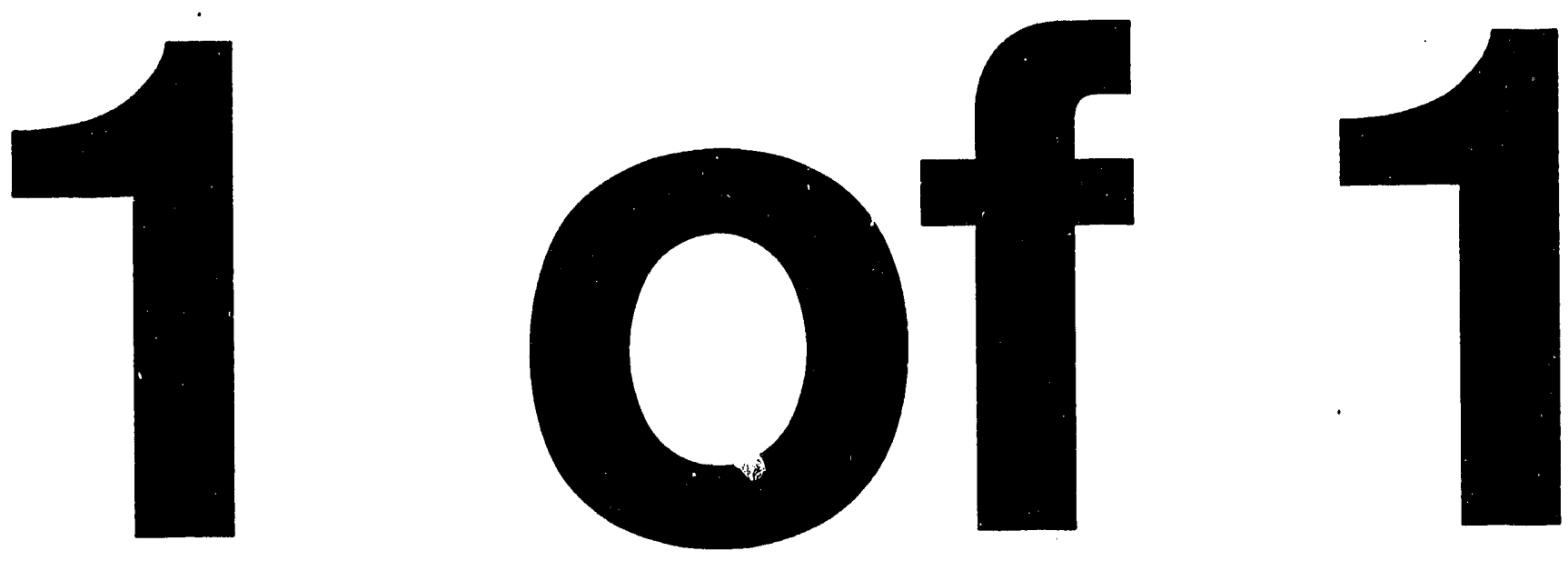


\title{
PERFORMANCE AND OPERATING RESULTS FROM THE DEMONSTRATION OF ADVANCED COMBUSTION TECHNIQUES FOR WALL-FIRED BOILERS
}

\author{
John N. Sorge \\ Southern Company Services, Inc. \\ P. O. Box 2625 \\ Birmingham, Alabama 35202 \\ A. L. Baldwin \\ U. S. Department of Energy \\ P. O. Box 10940 \\ Pittsburgh, PA 15236
}

\begin{abstract}
This paper discusses the technicai progress of a U. S. Department of Energy Innovative Clean Coal Technology project demonstrating advanced wall-fired combustion techniques for the reduction of nitrogen oxide (NOx) emissions from coal-fired boilers. The primary objective of the demonstration is to determine the long-term performance of advanced overfire air and low NOx burners applied in a stepwise fashion to a $500 \mathrm{MW}$ boiler. A 50 percent NOx reduction target has been established for the project. The focus of this paper is to present the effects of excess oxygen level and burner settings on NOx emissions and unburned carbon levels and recent results from the phase of the project when low NOx burners were used in conjunction with advanced overfire air.
\end{abstract}

\section{DISCLAIMER}

\begin{abstract}
This report was prepared as an account of work sponsored by an agency of the United States Government. Neither the United States Government nor any agency thereof, nor any of their employees, makes any warranty, express or implied, or assumes any legal liability or responsibility for the accuracy, completeness, or usefulness of any information, apparatus, product, or process disclosed, or represents that its use would not infringe privately owned rights. Reference herein to any specific commercial product, process, or service by trade name, trademark, manufacturer, or otherwise does not necessarily constitute or imply its endorsement, recommendation, or favoring by the United States Government or any agency thereof. The views and opinions of authors expressed herein do not necessarily state or reflect those of the United States Government or any agency thereof.
\end{abstract}

Presented at the U.S. DOE Second Annual Clean Coal Technology Conference September 7-9, 1993, Atlanta, Georgia USA 


\section{TABLE OF ABBREVIATIONS}

$\begin{array}{ll}\text { AOFA } & \text { Advanced Overfire Air } \\ \text { ASME } & \text { American Society of Mechanical Engineers } \\ \text { C } & \text { carbon } \\ \text { CF/SF } & \text { Controlled Flow/Split Flame } \\ \text { Cl } & \text { chlorine } \\ \text { CO } & \text { carbon monoxide } \\ \text { DAS } & \text { data acquisition system } \\ \text { DOE } & \text { United States Department of Energy } \\ \text { ECEM } & \text { extractive continuous emissions monitor } \\ \text { EPA } & \text { Environmental Protection Agency } \\ \text { EPRI } & \text { Electric Power Research Institute } \\ \text { F } & \text { Fahrenheit } \\ \text { FC } & \text { fixed carbon } \\ \text { FWEC } & \text { Foster Wheeler Energy Corporation } \\ \text { H } & \text { hydrogen } \\ \text { HHV } & \text { higher heating value } \\ \text { ICCT } & \text { Innovative Clean Coal Technology } \\ \text { b(s) } & \text { pound(s) } \\ \text { LNB } & \text { low NOx burner } \\ \text { LOI } & \text { loss on ignition } \\ \text { (M)Btu } & \text { (million) British thermal unit } \\ \text { MW } & \text { megawatt } \\ \text { N } & \text { nitrogen } \\ \text { NOx } & \text { nitrogen oxides } \\ \text { NSPS } & \text { New Source Performance Standards } \\ \text { O, O2 } & \text { oxygen } \\ \text { psig } & \text { pounds per square inch gauge } \\ \text { PTC } & \text { Performance Test Codes } \\ \text { RSD } & \text { relative standard deviation } \\ \text { S } & \text { sulfur } \\ \text { SCS } & \text { Southern Company Services } \\ \text { SO2 } & \text { sulfur dioxide } \\ \text { UARG } & \text { Utility Air Regulatory Group } \\ \text { VM } & \text { volatile matter } \\ & \end{array}$




\section{INTRODUCTION}

This paper discusses the technical progress of one of the U. S. Department of Energy's Innovative Clean Coal Technology (ICCT) projects demonstrating advanced combustion techniques for the reduction of nitrogen oxide (NOx) emissions from wall-fired boilers. This demonstration is being conducted on Georgia Power Company's Plant Hammond Unit 4, a 500 MW, pre-NSPS (New Source Performance Standards), wall-fired boiler. Plant Hammond is located near Rome, Georgia, northwest of Atlanta.

This project is being managed by Southern Company Services, Inc. (SCS) on behalf of the project co-funders: The Southern Company, the U. S. Department of Energy (DOE), and the Electric Power Research Institute (EPRI). In addition to SCS, Southern includes the five electric operating companies: Alabama Power, Georgia Power, Gulf Power, Mississippi Power, and Savannah Electric and Power. SCS provides engineering and research services to the Southern electric system. The ICCT program is a jointly funded effort between DOE and industry to move the most promising advanced coal-based technologies from the research and development (R\&D) stage to the commercial marketplace. The goal of ICCT projects is the demonstration of commercially feasible, advanced coal-based technologies that have already reached the "proof-ofconcept" stage. The ICCT projects are jointly funded endeavors between the government and the private sector in which the industrial participant contributes at least 50 percent of the total project cost. The DOE is participating through the Office of Clean Coal Technology at the Pittsburgh Energy Technology Center (PE TC).

The primary objective of this demonstration is to determine the long-term effects of commercially available low NOx combustion technologies on NOx emissions and boiler performance. Shortterm tests of each technology are also being performed to provide engineering information about emissions and performance trends [1]. Achieving 50 percent NOx reduction using combustion modifications is the goal of this project.

Following a brief unit and technology review, this paper focuses on (1) results of efforts to establish the relationship between NOx emissions and unburned carbon and (2) recent results from the low NOx burner (LNB) plus advanced overfire (AOFA) test phase.

\section{UNIT AND TECHNOLOGY REVIEW}

Georgia Power Company's Plant Hammond Unit 4 is a Foster Wheeler Energy Corporation (FWEC) opposed wall-fired boiler, rated at $500 \mathrm{MW}$ gross, with design steam conditions of 2500 
psig and $1000 / 1000^{\circ} \mathrm{F}$ superheat/reheat temperatures, respectively. The unit was placed into commercial operation on December 14, 1970. Prior to the LNB retrofit, six FWEC Planetary Roller and Table type mills provided pulverized eastern bituminous coal (12,900 Btu/lb, 33\% VM, $53 \% \mathrm{FC}, 72 \% \mathrm{C}, 1.7 \% \mathrm{~S}, 1.4 \% \mathrm{~N}, 10 \%$ ash) to 24 pre-NSPS, Intervane burners. The burners are arranged in a matrix of 12 burners $(4 \mathrm{~W} \times 3 \mathrm{H})$ on opposing walls with each mill supplying coal to four burners per elevation.

During a spring 1991 unit outage, the Intervane burners were replaced with FWEC Controlled Flow/Split Flame (CF/SF) burners. In the CF/SF burner, secondary combustion air is divided between inner and outer flow cylinders (Figure 1). A sliding sleeve damper regulates the total secondary air flow entering the burner and is used to balance the burner air flow distribution. An adjustable outer register assembly divides the burner's secondary air into two concentric paths and also imparts some swirl to the air streams. The secondary air that traverses the inner path, flows across an adjustable inner register assembly that, by providing a variable pressure drop, apportions the flow between the inner and outer flow paths. The inner register also controls the degree of additional swirl imparted to the coal/air mixture in the near throat region. The outer air flow enters the furnace axially, providing the remaining air necessary to complete combustion. An axially movable inner sleeve tip provides a means for varying the primary air velocity while maintaining a constant primary flow. The split flame nozzle segregates the coal/air mixture into four concentrated streams, each of which forms an individual flame when entering the furnace.

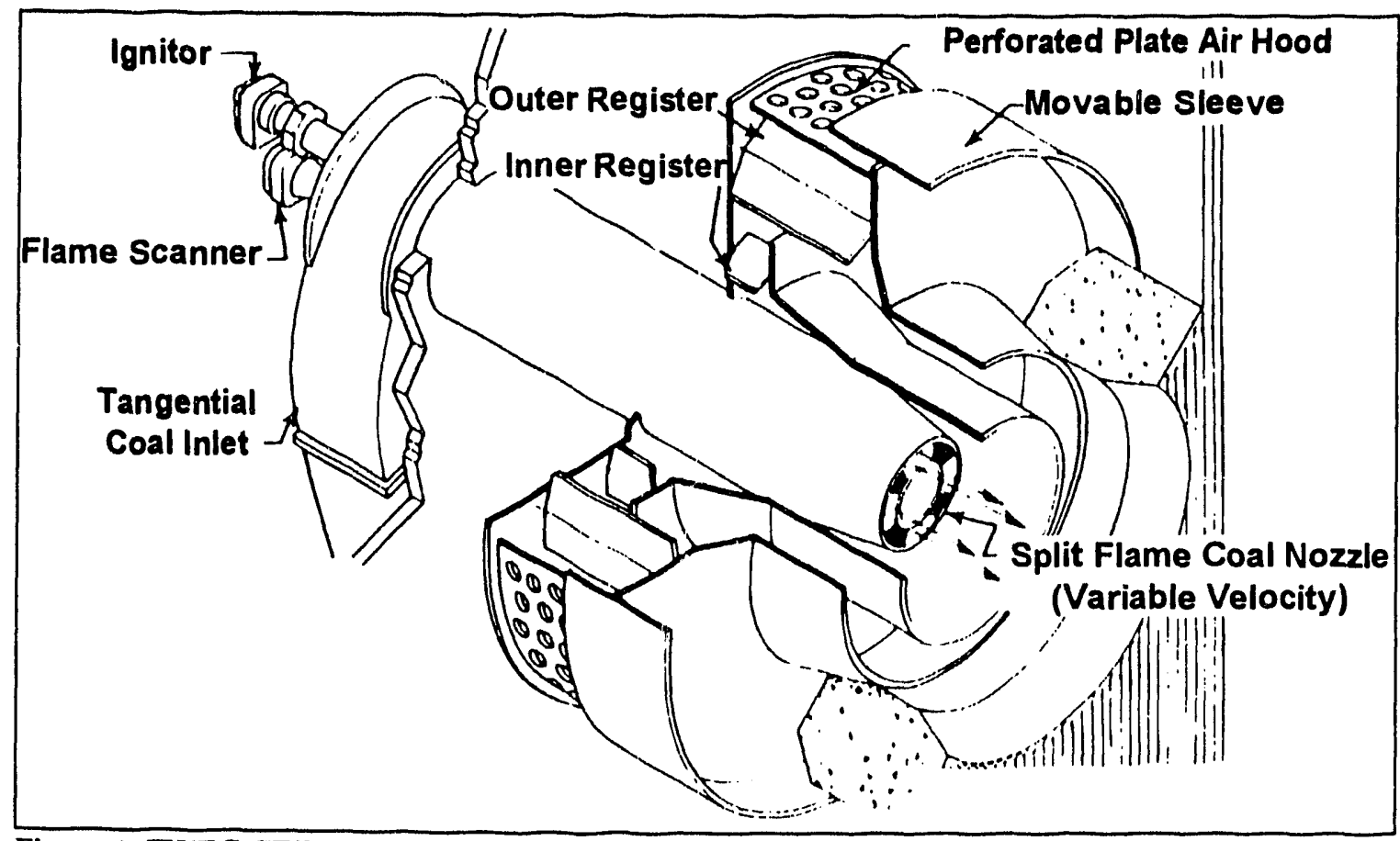

Figure 1. FWEC CF/SF Low NOx Burners 
This segregation minimizes mixing between the coal and the primary air, assisting in the staged combustion process.

As part of this demonstration project, the unit was also retrofit with an Advanced Overfire Air (AOFA) system (Figure 2). The FWEC design diverts air from the secondary air ductwork and incorporates four flow control dampers at the corners of the overfire air windbox and four overfire air ports on both the front and rear furnace walls. Due to budgetary and physical constraints, FWEC designed an AOFA system rnore suitable to the project and unit than that originally proposed. Six air purts per wall were proposed instead of the as-installed configuration of four per wall.

During the course of the demonstration, the unit was also retrofitted with four Babcock \& Wilcox MPS 75 mills (two each during the spring 1991 and spring 1992 outages). The unit is equipped with a coldside ESP and utilizes two regenerative secondary air preheaters and two regenerative primary air heaters. The unit was designed for pressurized furnace operation but was converted to balanced draft operation in 1977.

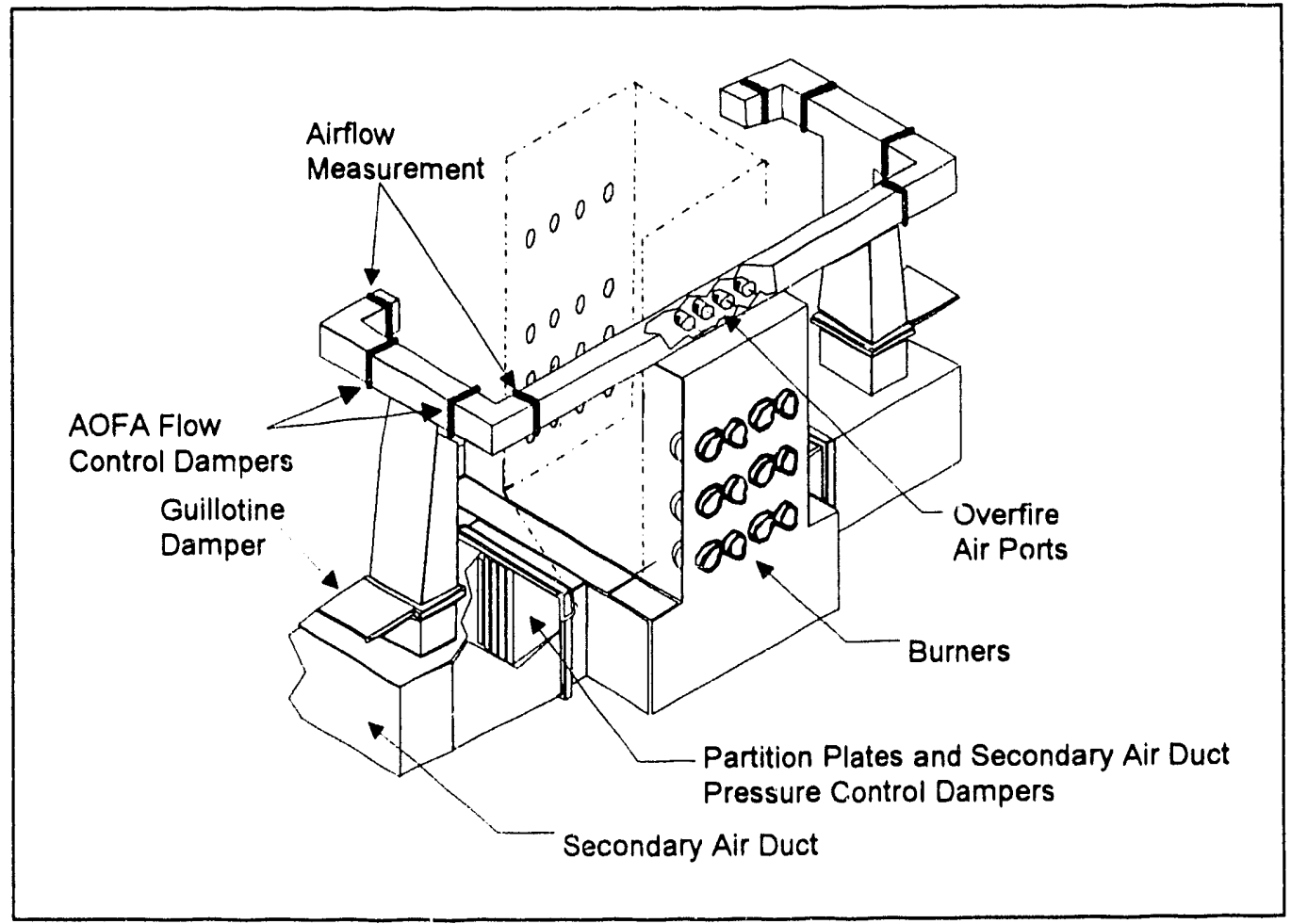

Figure 2. FWEC Advanced Overfire Air System 


\section{REVIEW OF PRIOR TESTING}

Baseline, AOFA, and LNB test phases have been completed (Table 1). Short-term and long-term baseline testing was conducted in an "as-found" condition from November 1989 through March 1990. Following retrofit of the AOFA system during a four-week outage in spring 1990, the AOFA configuration was tested from August 1990 through March 1991. The FWEC CF/SF low NOx burners were then installed during a seven week outage starting on March 8, 1991 and continuing to May 5, 1991. Following optimization of the LNBs and ancillary combustion equipment by FWEC personnel, LNB testing was commenced during July 1991. However, due to significant post-LNB increases in precipitator fly ash loading and gas flow rate and also, increases in fly ash LOI which adversely impacted stack particulate emissions, the unit was run below $300 \mathrm{MW}$ from September to November 1991 [2]. Following installation of an ammonia flue gas conditioning system, the unit was able to return to full load operation and complete the LNB test phase during January 1992.

\begin{tabular}{|c|l|c|}
\hline Phase & \multicolumn{1}{|c|}{ Description } & Date \\
\hline 0 & Pre-Award Negotiations & $8 / 89-4 / 90$ \\
1 & Baseline Characterization & \\
2 & Advanced Overfire Air Retrofit (AOFA) \& Characterization & $4 / 90-3 / 91$ \\
$3 \mathrm{~A}$ & Low NOx Burner Retrofit (LNB) \& Characterization & $3 / 91-1 / 92$ \\
$3 \mathrm{~B}$ & LNB+AOFA Characterization & $1 / 92-8 / 93$ \\
4 & Digital Controls & $9 / 93-6 / 95$ \\
5 & Final Reporting and Disposition & $6 / 95-12 / 95$ \\
\hline
\end{tabular}

Table 1. Project Schedule

Given the extended LNB test phase, insufficient time was available to complete the full requirements of the LNB+AOFA test phase prior to the spring 1992 outage; therefore it was decided to collect abbreviated data prior to this outage and comprehensive data following the outage. Following the outage, it was found that the AOFA had exacerbated the stack particulate emissions and the unit was again load limited, this time to $450 \mathrm{MW}$. While efforts were made to resume full load operation, special tests (i.e., NOx vs. LOI) were performed and long-term data collected. On March 30, 1993, Hammond Unit 4 resumed full load operation and comprehensive testing in the LNB+AOFA configuration began.

\section{NOX VS. LOI TESTING}

The NOx versus LOI testing was conducted between October 12 and 28, 1992. The primary purpose of these tests was to determine the effects of various burner settings and mill operation on NOx emissions and unburned carbon levels in the fly ash. To assess the effects of each parameter, the test matrix was designed so that a single parameter was varied each test day and all 
other parameters were held constant to the extent possible. The parameters tested were (1) excess air, (2) mill coal flow bias, (3) burner sliding tip position, (4) burner outer register position, and (5) burner inner register position. The range of values tested is shown in Table 2. Mill characterization (i.e., primary air and coal through each mill; coal and air distributions; and particle size determination in each coal pipe) was also performed as part of this test program. Unless specified otherwise, all tests were run at the following conditions: (1) nominal $450 \mathrm{MW}$, (2) all mills in service with equal flows, and (3) overfire air flow set to $200,000 \mathrm{lb} / \mathrm{hr}(600,000$ $\mathrm{lb} / \mathrm{hr}$ of overfire air is normal for LNB+AOFA operation at this load). The tests were conducted at reduced loads to adhere to stack particulate compliance limits while overfire flow was maintained at the reduced level to prevent excessive slagging or overheating of the AOFA ports. Because of the different operating conditions (load and overfire air flow rates), the absolute values of emissions are difficult to correlate with previous test phase results; however, the intent of this test segment was to perform sensitivity studies, and the influence of the independent variables on NOx emissions and LOI at the tested condition should be indicative of the sensitivities at full load with LNBs and no overfire air.

\begin{tabular}{|c|c|c|c|}
\hline \multirow[b]{2}{*}{ Parameter } & \multirow[b]{2}{*}{ Nominal Value } & \multicolumn{2}{|c|}{ Range Tested } \\
\hline & & Low & High \\
\hline Excess Air & $4 \%$ & $2.8 \%$ & $5.0 \%$ \\
\hline Sleeve Damper & $\begin{array}{l}\text { 7" Outer burner columns } \\
4^{\prime \prime} \text { Inner burner columns }\end{array}$ & $\begin{array}{c}\text { Not } \\
\text { Adjusted }\end{array}$ & $\begin{array}{c}\text { Not } \\
\text { Adjusted }\end{array}$ \\
\hline Inner Register & $-15 \%$ & Nominal & Nominal $+40 \%$ \\
\hline Outer Register & $-60 \%$ & $-20 \%$ of nominal & $+20 \%$ of nominal \\
\hline Sliding Tip & +4 inches & +2 inches & +4 inches \\
\hline Mill Bias & No bias & $\begin{array}{l}\text { Upper Mills }+10 \% \\
\text { Lower Mills }-10 \%\end{array}$ & $\begin{array}{l}\text { Upper Mills }-10 \% \\
\text { Lower Mills }+10 \%\end{array}$ \\
\hline
\end{tabular}

Table 2. Hammond 4 / NOx vs. LOI Tests / Parameters Tested

Figure 3 shows the range of the NOx and LOI values which resulted from this testing. NOx emissions and LOI levels varied from approximately $0.44 \mathrm{lb} / \mathrm{MBtu}$ to $0.57 \mathrm{lb} / \mathrm{MBtu}$ and 10 percent to 3 percent, respectively. With the exception of the excess $\mathrm{O}_{2}$ tests, the NOx (in $\mathrm{lb} / \mathrm{MBtu}$ ) and LOI values shown in this figure are adjusted to a nominal 4 percent excess $\mathrm{O}_{2}$ operating level using the slopes of the NOx and LOI vs. $\mathrm{O}_{2}$ curves found during these tests. This adjustment was made to compensate for the test to test variations in excess $\mathrm{O}_{2}$ levels. As expected, excess $\mathrm{O}_{2}$ level had a considerable effect on both NOx and LOI (Figure 4). For the other parameters considered, within the range of adjustments tested, mill bias and sliding tip position had the greatest influence on NOx and LOI (Figures 5 and 6). As can be seen from these graphs, there is some flexibility in selecting the optimum operating point and making 
tradeoffs between NOx emissions and fly ash LOI; however, much of the variation was the result of changes in excess $\mathrm{O}_{2}$.

This can be seen more clearly in Figure 7 in which all the sensitivities are plotted. This figure shows for excess $\mathrm{O}_{2}$, mill bias, inner register, and sliding tip, any adjustments to reduce NOx emissions are at the expense of increased LOI. In contrast, the slope of the outer register characteristic suggests that an improvement in both NOx emissions and LOI can be achieved by adjustment of this damper. However, due to the relatively small impact of the outer register adjustment on both NOx emissions and LOI, it is likely that the positive NOx / LOI slope is an artifact of process noise. It should be stressed that Figures 3 and 7 are parametric plots and that neither NOx or LOI are independent variables.

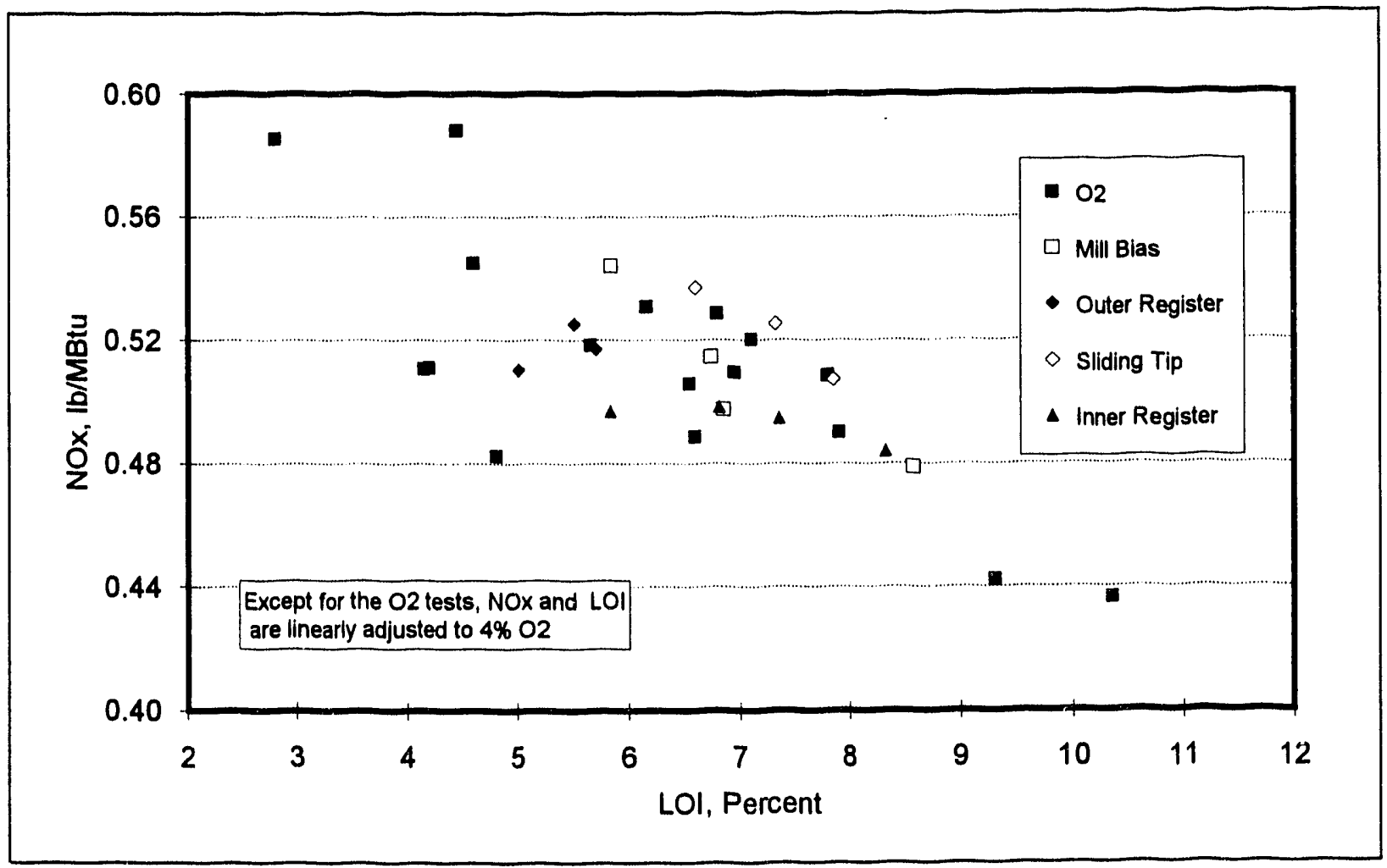

Figure 3. Hammond 4 / NOx vs. LOI Tests / All Tests 


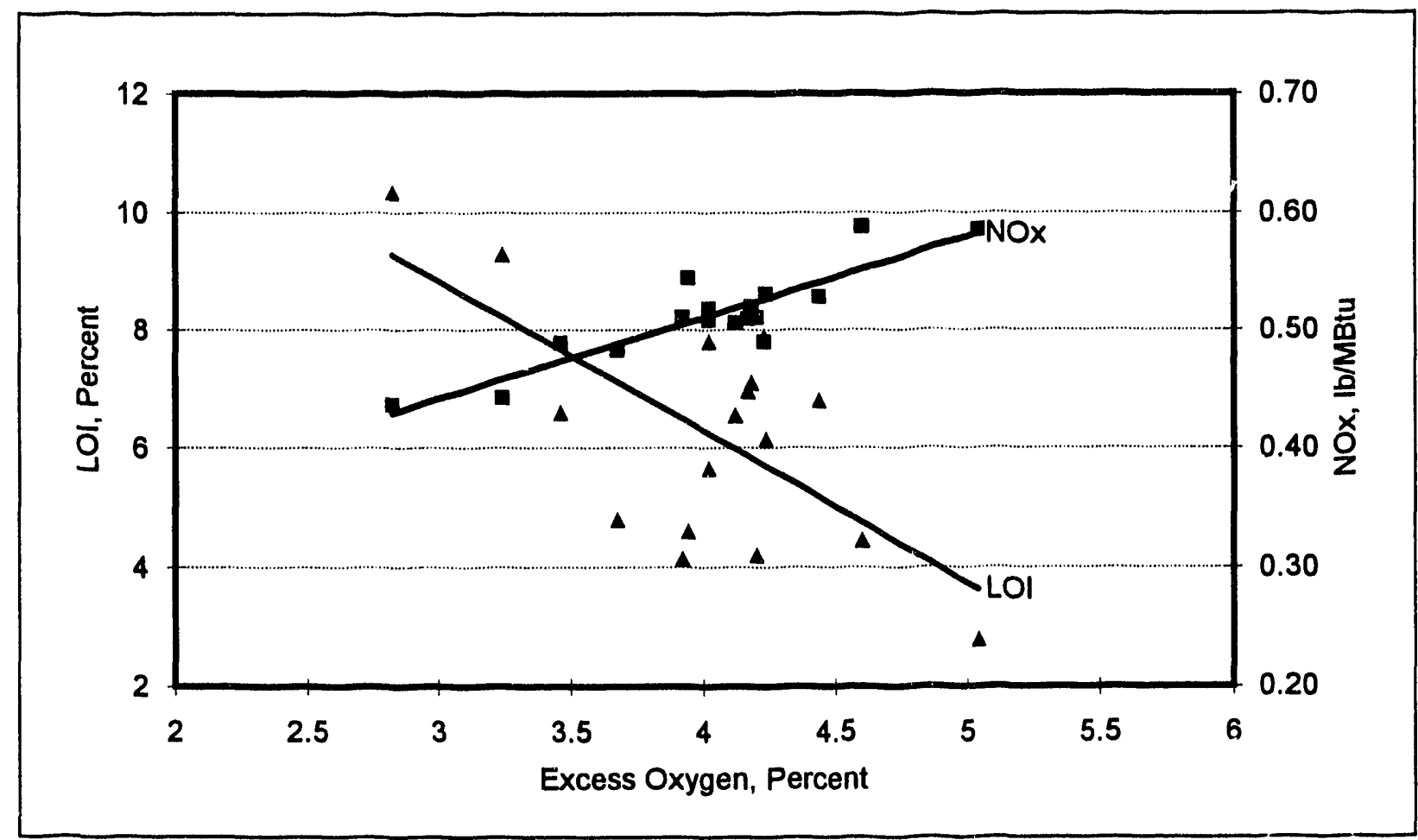

Figure 4. Hammond 4 / NOx vs. LOI Tests / $\mathrm{O}_{2}$ Sensitivity

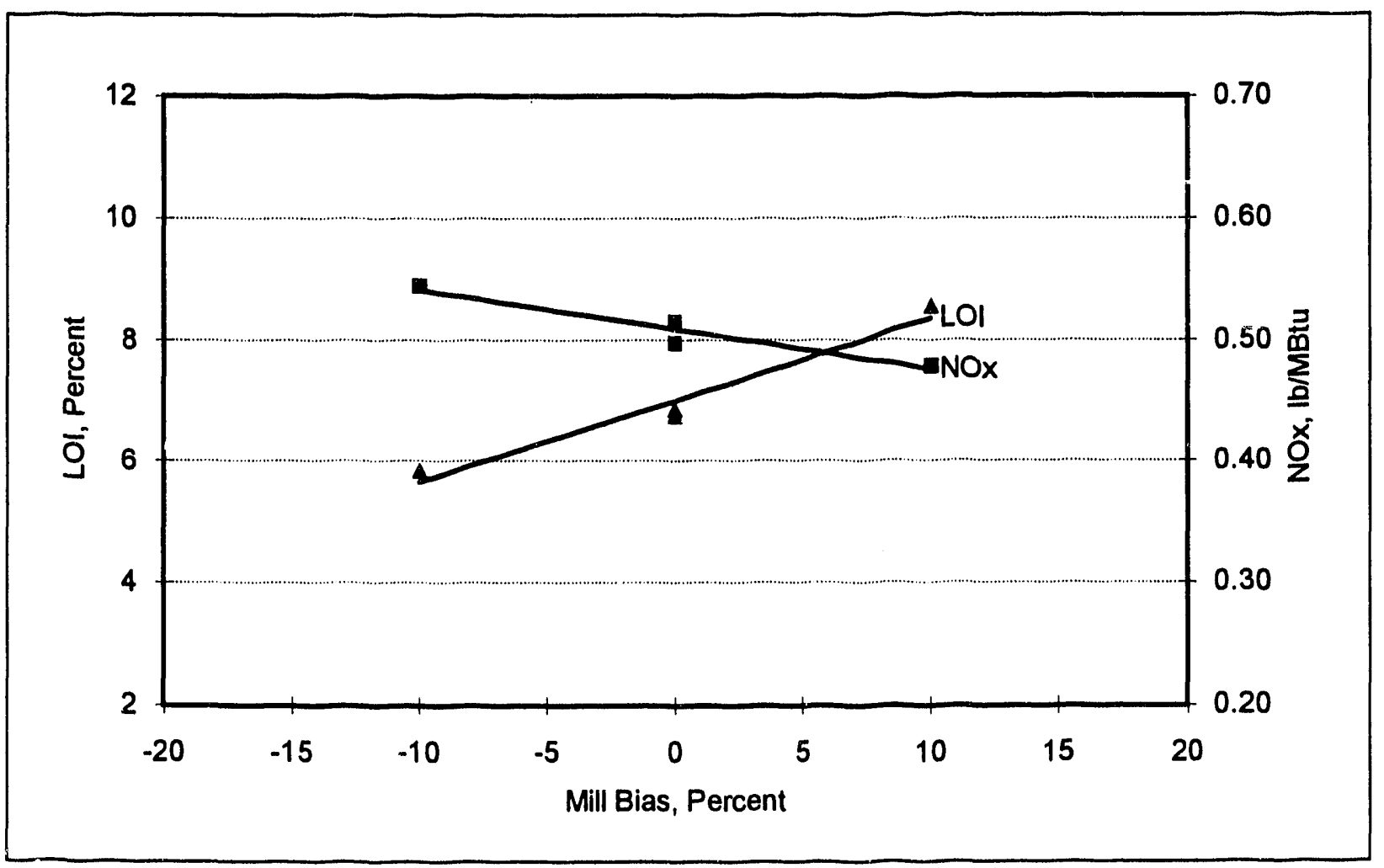

Figure 5. Hammond 4 / NOx vs. LOI Tests / Mill Bias Sensitivity 


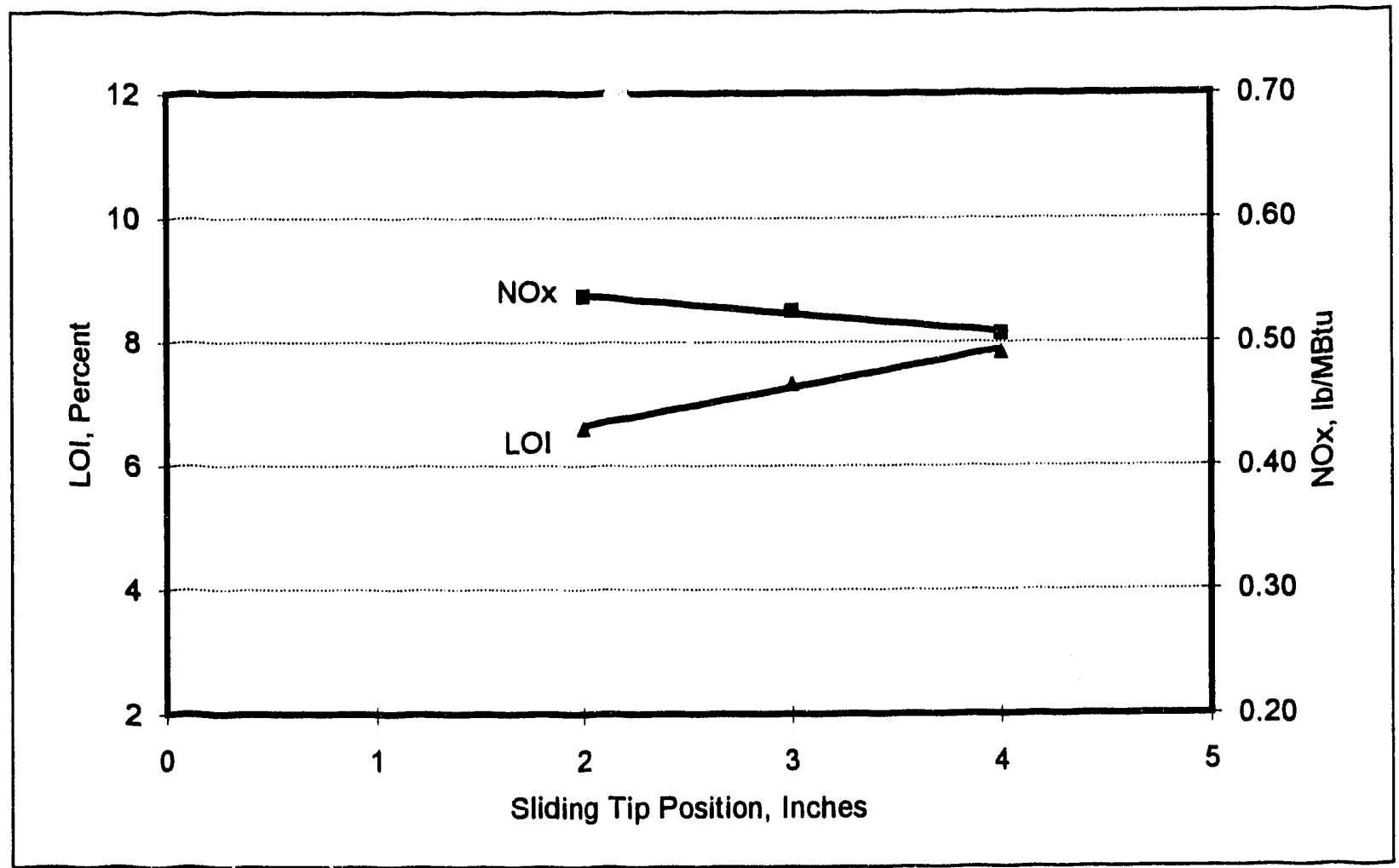

Figure 6. Hammond 4 / NOx vs. LOI Tests / Sliding Tip Position

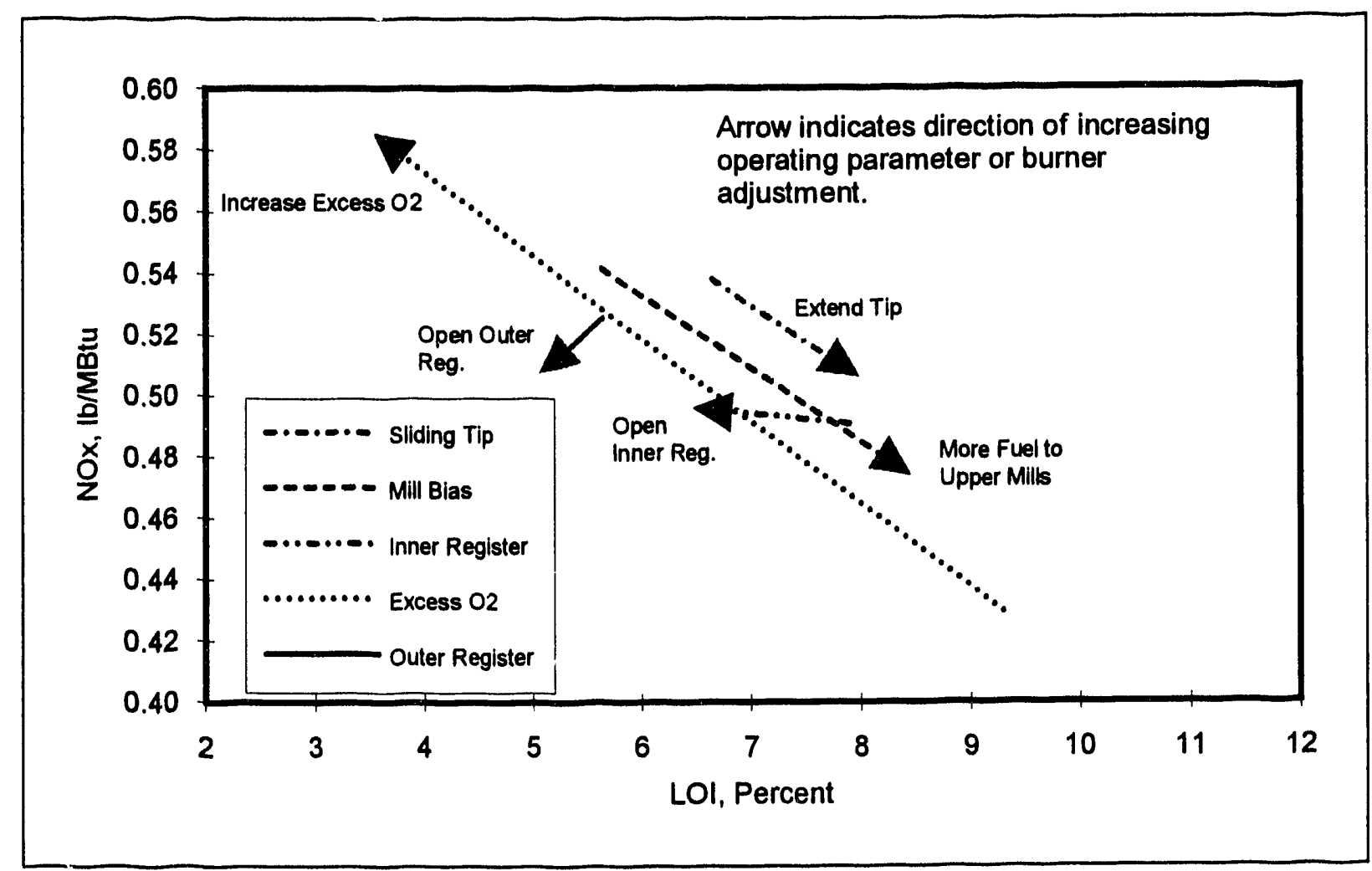

Figure 7. Hammond 4/ NOx vs. LOI Tests / All Sensitivities 


\section{LNB+AOFA CHARACTERIZATION}

Following completion of the LNB test phase during January 1992, testing in the low NOx burner and advanced overfire air configuration was to begin with completion scheduled for late March 1992. However, due to delays associated with increased stack particulate emissions following the LNB installation, testing in the LNB+AOFA configuration could not be completed prior to the spring 1992 outage during which two new mills were to be installed. To obtain operating data prior to this outage, abbreviated testing (designated 3B') in the LNB+AOFA configuration was performed during February and March 1992. Following the spring 1992 outage, the unit ran at reduced loads (less than $450 \mathrm{MW}$ ) until spring 1993 to maintain stack particulate compliance. During this period, long-term data were collected and the NOx vs. LOI tests (discussed above) were performed.

Following resumption of full load operation on March 26, 1993, FWEC personnel re-optimized the unit starting March 30, 1993 and continuing through May 6, 1993. As shown in Figure 8, burner settings, with the exception of the burner tips, are similar to those used for the NOx vs. LOI test segment. The AOFA flow schedule is also shown in Figure 8. Since the AOFA is not automatically controlled, the operator must manually maintain not only the total overfire air flow rate but also balance the flows to the four corners of the AOFA windbox. This task has proven difficult during long-term, normal unit dispatch.

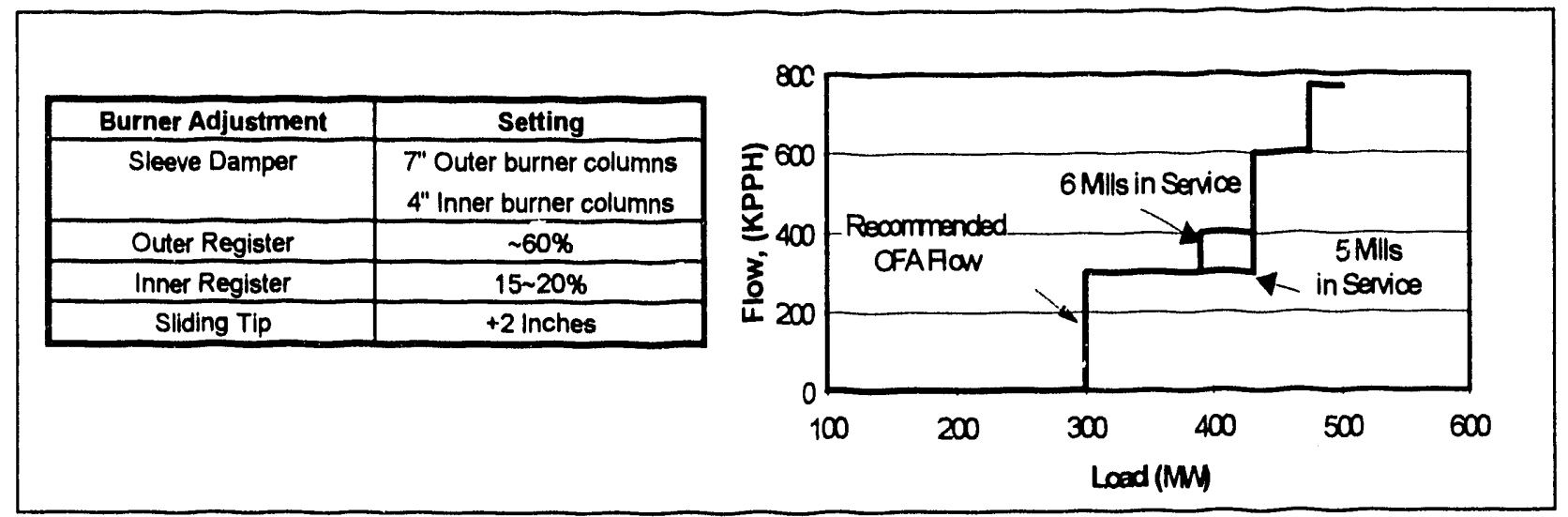

Figure 8. LNB+AOFA Burner Settings and AOFA Schedule

Subsequent to the re-optimization, comprehensive testing using LNB plus AOFA began. As of June 30, 1993, sixty-seven (67) diagnostic and performance tests have been conducted. As shown in Figure 9, full load NOx emissions are approximately $0.43 \mathrm{lb} / \mathrm{MBtu}$ with corresponding fly ash loss-on-ignition (LOI) values of 8 percent. At low loads (300 MW), NOx emissions and LOI are approximately $0.32 \mathrm{lb} / \mathrm{MBtu}$ and 5.5 percent, respectively. Also shown in Figure 9 are 
the results from the February-March 1992 testing. NOx emissions for the latest round of testing are considerably below the NOx levels found in these earlier tests. The additional NOx reduction is most likely the result of re-optimization of the combustion system allowing lower excess air operation for the most recent testing (approximately 4 percent vs. 3.7 percent).

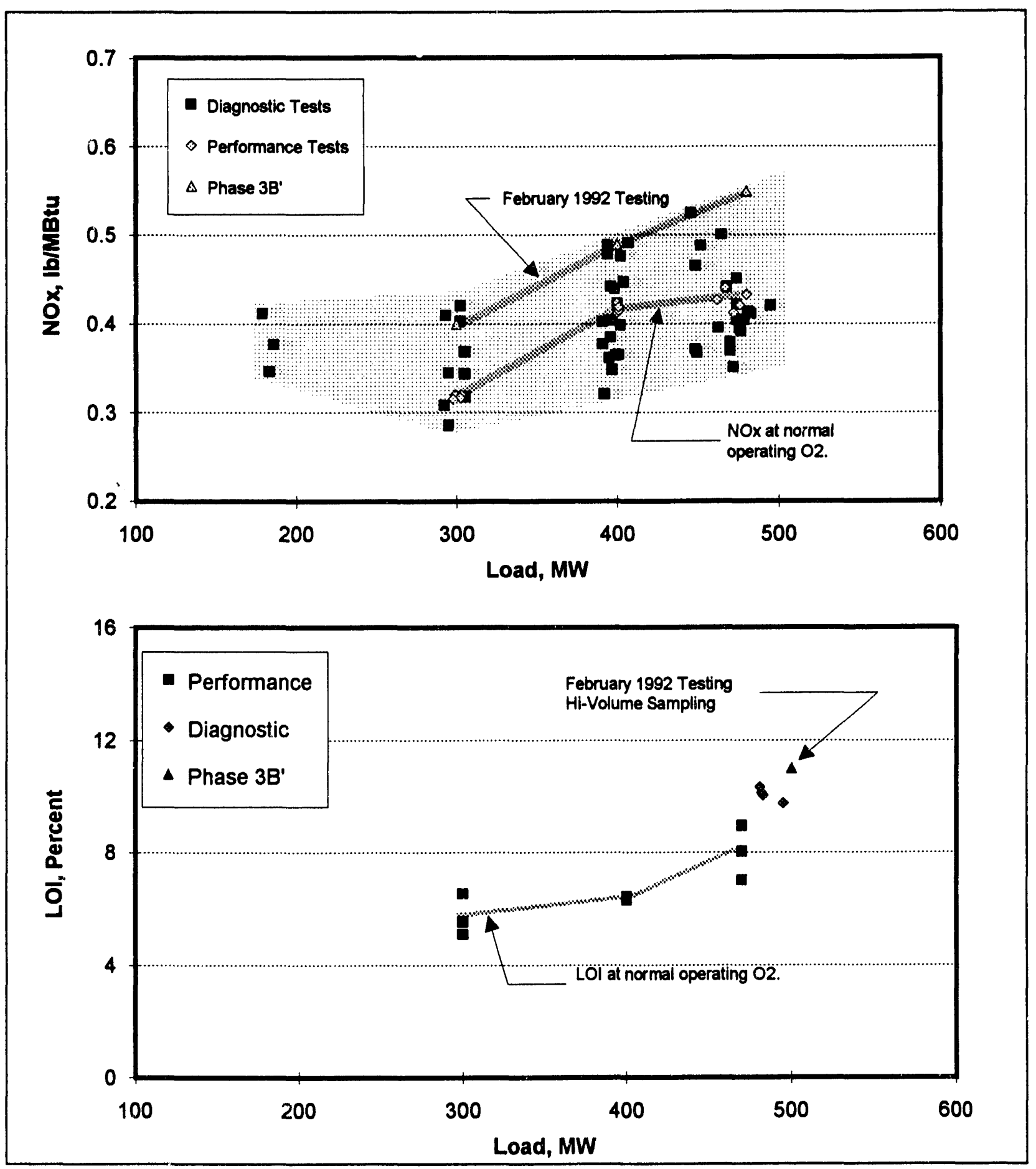

Figure 9. LNB+AOFA Short-Term NOx Emissions and Fly Ash Loss-On-Ignition 
Long-term testing of the LNB+AOFA is in progress and is scheduled to continue until August 1993. As of June 30, 1993, twenty-nine (29) days of valid long-term data have been collected. Full load, long-term NOx emissions are approximately $0.42 \mathrm{lb} / \mathrm{MBtu}$, which is consistent with that found during the performance testing (Figure 10). However, at $300 \mathrm{MW}$, long-term NOx emissions are near $0.37 \mathrm{lb} / \mathrm{MBtu}$, nearly $0.05 \mathrm{lb} / \mathrm{MBtu}$ higher than the short-term emissions at the same load with approximately the same excess air and AOFA flow rate. The cause of this disparity is unknown. Despite this difference, the short-term data is within the $90^{\text {th }}$ percentile range of the long-term data. As with the short-term data, a substantial difference exist between the current long-term NOx emissions and those previously recorded. This difference is again likely the result of re-optimization of the combustion system. Approximately 60 days of long-term data will be collected in this configuration; therefore, the final results may change when the complete data set is analyzed.

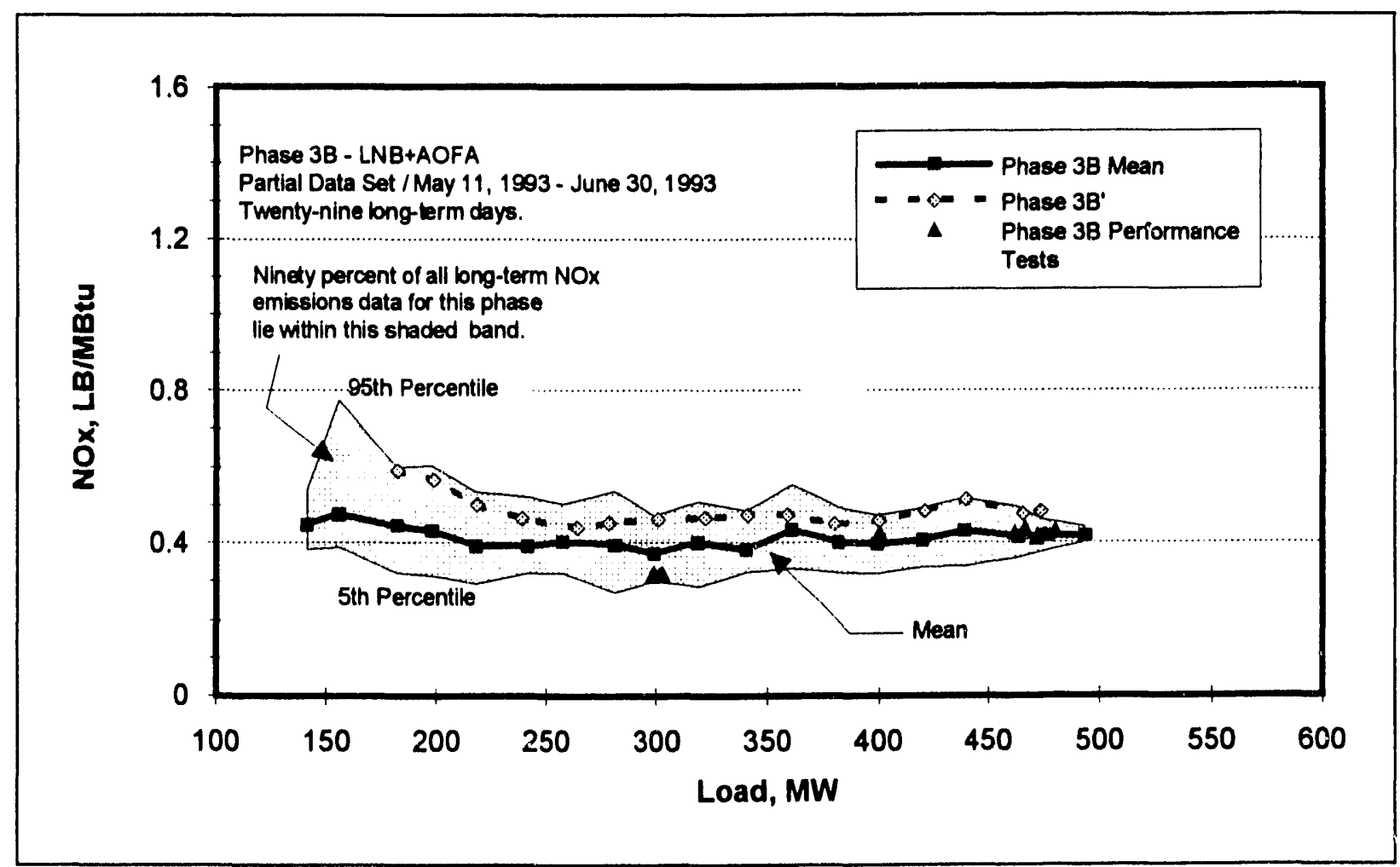

Figure 10. LNB+AOFA Long-Term NOx Emissions

\section{DATA COMPARISON}

As previously discussed, baseline, AOFA, and LNB test phases have been completed. Testing in the LNB+AOFA configuration is scheduled for completion in August 1993. The following paragraphs compare the results from these phases. 


\section{NOx Reductions}

Figure 11 compares the baseline, AOFA, LNB, and LNB+AOFA long-term NOx emissions data for Hammond Unit 4. Baseline testing was performed in an "as-found" condition and the unit was not tuned for NOx emissions for this test phase. For the AOFA, LNB, and LNB+AOFA test phases, following optimization of the unit by FWEC personnel, the unit was operated according to FWEC instructions provided in the design manuals. As shown, the AOFA and LNBs provide a long-term, full load, NOx reduction of 24 and 48 percent, respectively. For the LNBs, the NOx reduction averaged approximately 50 percent over the load range; however, the effectiveness of the AOFA system decreased with decreasing load. For the baseline, AOFA, and LNB phases, the NOx vs. load characteristic is based on normal operation of the unit in excess of 51 days. The full load, long-term NOx emissions reduction in the LNB+AOFA configuration with the partial data set is approximately 65 percent at full load. These results may change when the complete data set is analyzed.

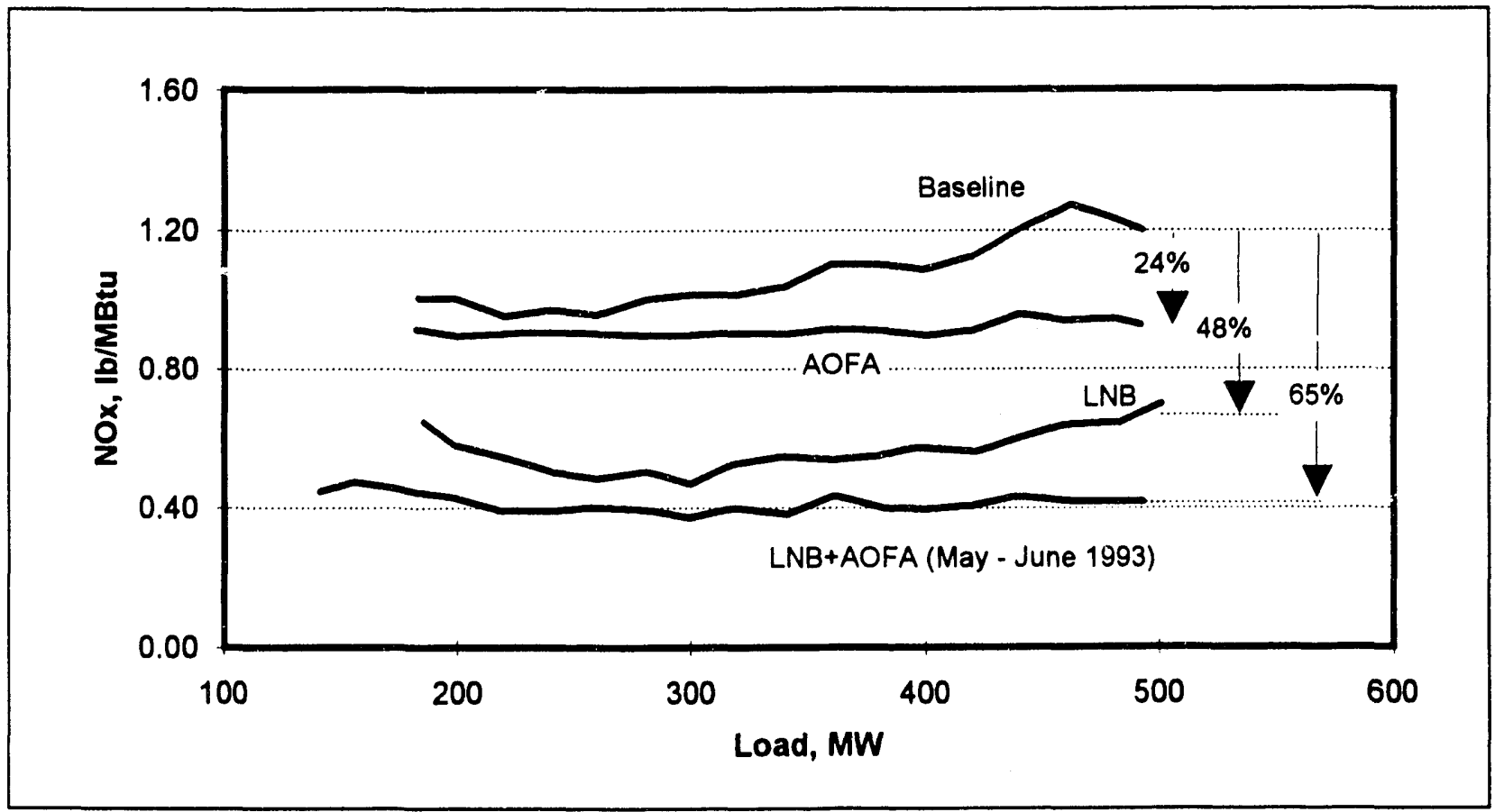

Figure 11. Hammond 4 / Long-Term NOx Emissions

The NOx emissions averaged over the baseline, AOFA, and LNB test phases are shown in Table 3. Since NOx emissions are generally dependent on unit load, the NOx values shown in this table are influenced by the load dispatch of the unit during the corresponding test frame. Results from the LNB+AOFA test phase will be determined at the end of the long-term data collection period. 


\begin{tabular}{|l|cc|cc|cc|}
\hline \multirow{2}{*}{ Unit Configuration } & \multicolumn{2}{|c|}{ Baseline } & \multicolumn{2}{c|}{ AOFA } & \multicolumn{2}{c|}{ LNB } \\
& Mean & RSD,\% & Mean & RSD,\% & Mean & RSD,\% \\
\hline Number of Daily Averaged Values & 52 & - & 86 & - & 94 & - \\
Average Load (MW) & 407 & 9.4 & 386 & 17.9 & 305 & 17.7 \\
Average NOx Emissions (lb/MBtu) & 1.12 & 9.5 & 0.92 & 8.6 & 0.53 & 13.7 \\
Average O2 Level (percent at stack) & 5.8 & 11.7 & 7.3 & 12.6 & 8.4 & 7.7 \\
NOx 30 Day Achievable Emission Limit (lb/MBtu) & 1.24 & - & 1.03 & - & 0.64 & - \\
NOx Annual Achievable Emission Limit (lb MBtu) & 1.13 & - & 0.93 & - & 0.55 & - \\
\hline
\end{tabular}

\section{Table 3. Long-Term NOx Emissions}

\section{LOI Performance}

The fly ash loss-on-ignition (LOI) values increased significantly for the AOFA and LNB test phases and similar increases have been experienced in the LNB+AOFA testing (Figure 12). These LOI increases were evident over the load range. The LOI measurements were made during each performance test using EPA's Method 17 at the secondary air heater outlet [3]. As shown in Table 4, mill performance was generally better in the AOFA, LNB, and LNB+AOFA test phases than during baseline. The improvement in coal fineness was likely responsible for the reduction in fly ash LOI levels during the May-August 1993 LNB+AOFA test phase. Although it is commorly recognized that fuel fineness can have a pronounced effect on fly ash LOI, results from Plant Smith, Plant Gaston, and other sources indicate the direct impact of fuel fineness on NOx emissions is small $[4,5,6]$. As previously reported, the post LNB retrofit increase in fly ash LOI along with increases in combustion air requirements and fly ash loading to the precipitator, has had an adverse impact on the unit's stack particulate emissions [2].

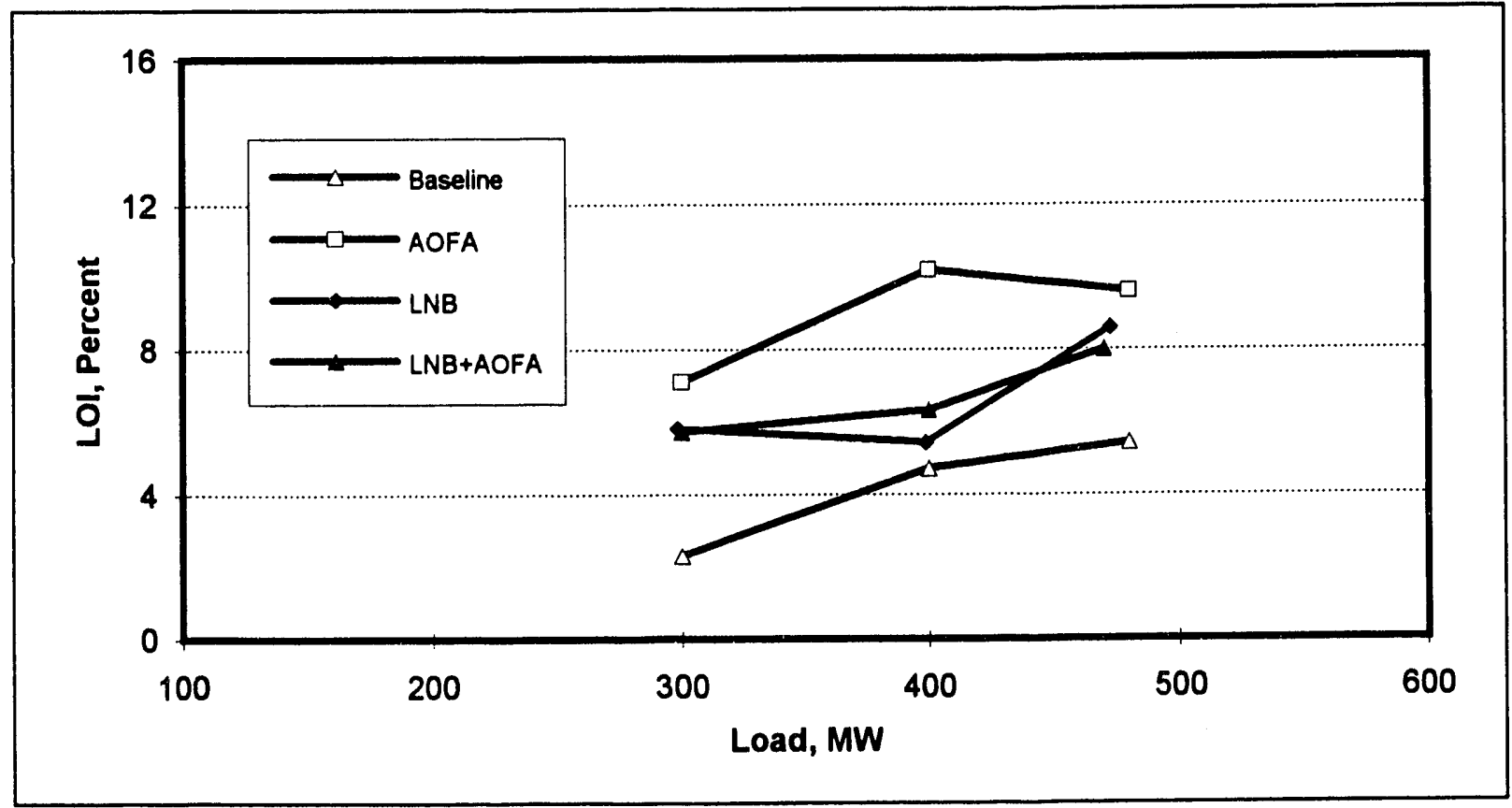

Figure 12. Hammond 4 / Fly Ash LOI 


\begin{tabular}{|c|c|c|}
\hline \multirow[b]{2}{*}{ Technology } & \multicolumn{2}{|c|}{ Coal Fineness } \\
\hline & $\begin{array}{c}\text { Passing } 200 \text { Mesh } \\
\text { Percent }\end{array}$ & $\begin{array}{c}\text { Remaining } 50 \text { Mesh } \\
\text { Percent }\end{array}$ \\
\hline Baseline & 63 & 2.8 \\
\hline AOFA & 67 & 2.6 \\
\hline LNB & 67 & 1.4 \\
\hline $\mathrm{LNB}+\mathrm{AOFA}$ & 74 & 0.6 \\
\hline
\end{tabular}

Table 4. Hammond 4/ Mill Performance Summary

\section{Excess 02 Levels}

Long-term, economizer outlet $\mathrm{O}_{2}$ levels for the AOFA, LNB, and LNB+AOFA test phases were generally higher than the corresponding baseline values (Figure 13). This change in $\mathrm{O}_{2}$ level for these configurations is mostly attributable to an increase in combustion air requirements for the low NOx combustion configurations; however, factors unrelated to the retrofits, such as leakage in the furnace backpass, can also affect these levels. The impact of this leakage and varying $\mathrm{O}_{2}$ levels on emissions and unit performance will be investigated and discussed in future reports.

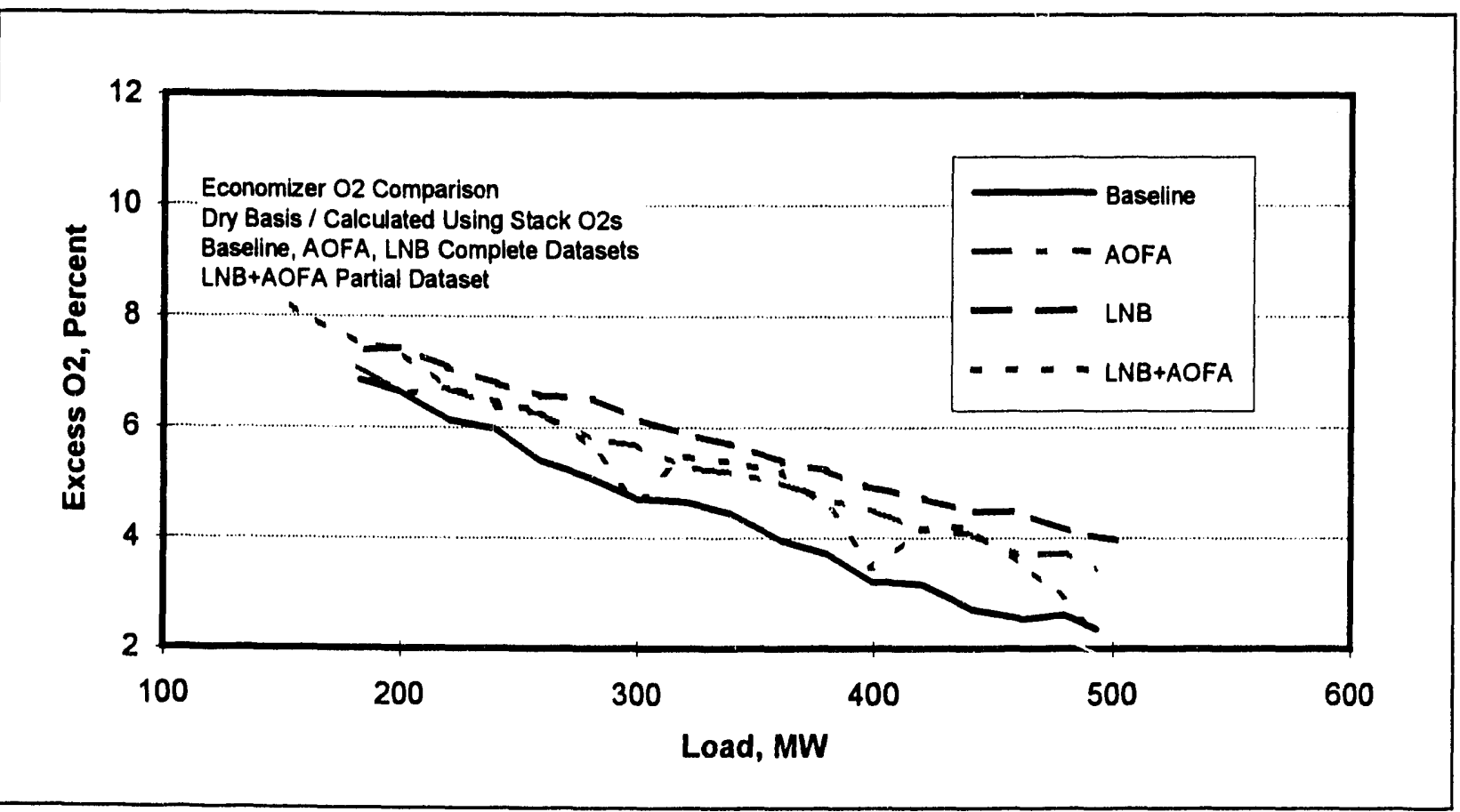

Figure 13. Hammond 4 / Economizer 02 


\section{CONCLUSIONS}

In conclusion, the results to date at Plant Hammond indicate:

- NOx emissions have been reduced to about 50 percent of baseline values by using low NOx burners alone. These reductions were sustainable over the long-term test period and were consistent over the entire load range. At Hammond, preliminary results indicate AOFA used in conjunction with the LNBs provide approximately 15 percent additional NOx reduction benefit over LNB alone.

- For all low NOx combustion configurations, the unit experienced significant performance impacts including increases in excess air and fly ash LOI.

- At Hammond 4, operational and burner adjustments which favorably impacted $\mathrm{NOx}$ emissions adversely affected fly ash unburned carbon levels.

\section{ACKNOWLEDGMENTS}

The authors wish to gratefully acknowledge the support and dedication of the following personnel: Mr. Ernie Padgett, Georgia Power Company, and Mr. Mike Nelson, Southern Company Services, for their coordination of the design and retrofit efforts, and Mr. Jose Perez, Instrumentation Specialist from Spectrum Systems, Inc. We also thank Mr. Jim Witt and Mr. Jimmy Horton of Southern Company Services for their work coordinating the procurement and installation of the instrumentation. We would also like to recognize the following companies for their outstanding testing and data analysis efforts: Energy Technology Consultants, Inc., Flame Refractories, Inc., Southern Research Institute, W. S. Pitts Consulting, and Radian Corporation. Finally, the support from Mr. David Eskinazi, EPRI Project Manager, and Mr. Stratos Tavoulareas, Energy Technologies Enterprise Corporation, is greatly appreciated.

\section{REFERENCES}

1. Advanced Wall-Fired Low NOx Combustion Demonstration - Phase 1 Baseline Tests, U. S. DOE ICCT II Demonstration Project, Interim Report, Southern Company Services, July 1991.

2. 500 MW Demonstration of Advanced Wall-Fired Combustion Techniques for the Reduction of Nitrogen Oxide (NOx) Emissions from Coal Fired Boilers - Technical Progress Report Third Quarter 1991, Birmingham, Alabama: Southern Company Services Inc., November 1991.

3. U. S. Environmental Protection Agency. Determination of Particulate Emissions from Stationary Sources (In-Stack Filtration Methods), Federal Register 43(37):7884. Washington, D. C.: Government Printing Office, February 23, 1978. 
4. Hardman, R. R., Smith, L. L., Tavoulareas, S., "Results from the ICCT T-Fired Demonstration Project Including the Effect of Coal Fineness on NOx Emissions and Unburned Carbon Levels, "EPA/EPRI 1993 Joint Symposium on Stationary Combustion NOx Control, May 24-27, 1993, Miami, Florida.

5. Sorge, J. N., Hardman, R. R., "The Effects of Low NOx Combustion on Unburned Carbon Levels in Wall-Fired Boilers," EPA/EPRI 1993 Joint Symposium on Stationary Combustion NOx Control, May 24-27, 1993, Miami, Florida.

6. Kinoshita, M., Kawamura, T., Kaneko, S., and Sakai, M., "New Approach to NOx Control Optimization and Unburnt Carbon Losses," EPA/EPRI 1989 Joint Symposium on Stationary Combustion NOx Control, March 6-9, 1989, San Francisco, California. 

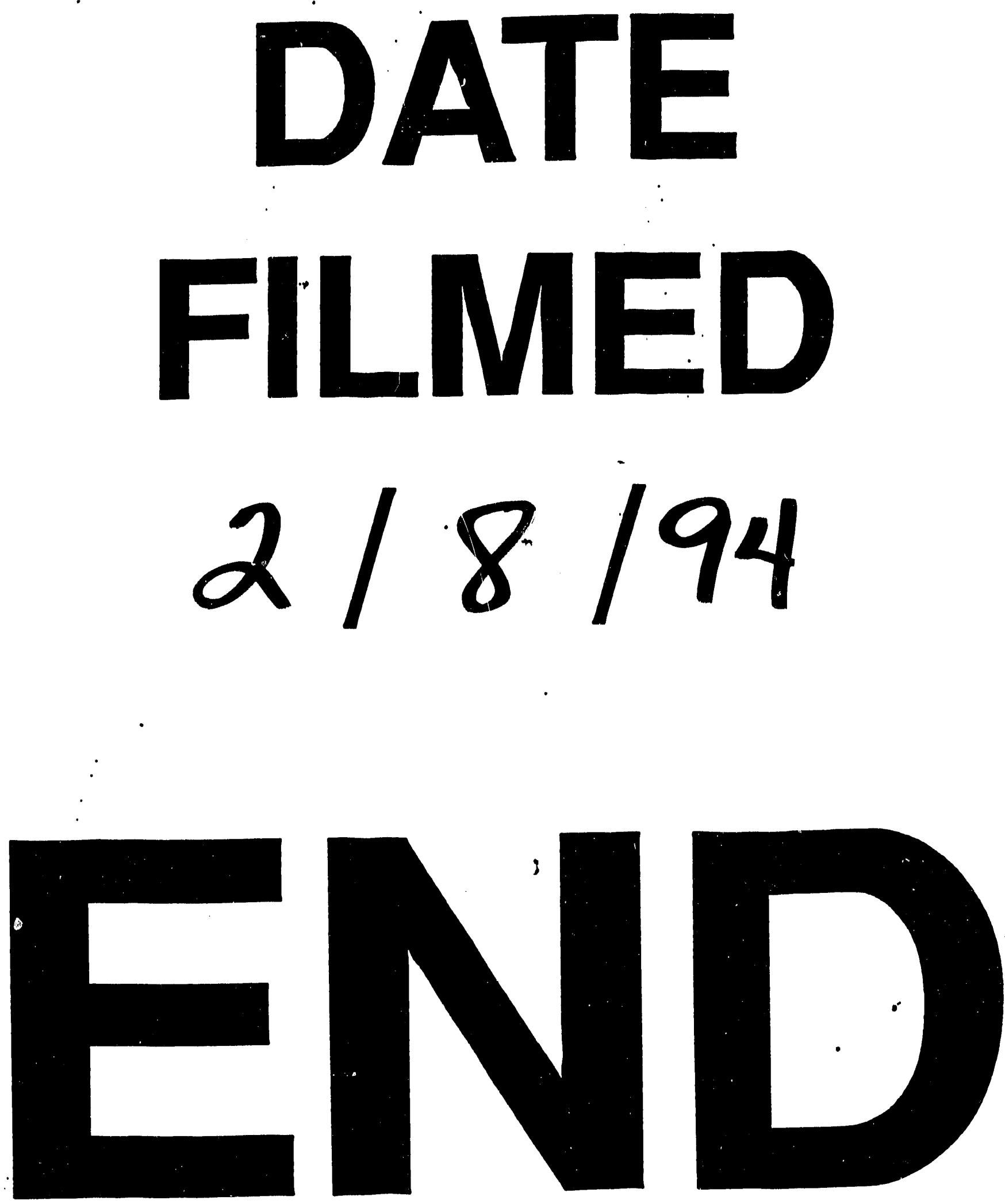
